Available online at http://www.anpad.org.br/bar

BAR, Rio de Janeiro, v. 10, n. 3, art. 2, pp. 263-280, July/Sept. 2013

\title{
Trust and Supplier-buyer Relationships: An Empirical Analysis
}

\author{
Luciana Marques Vieira \\ E-mail address: 1mvieira@unisinos.br \\ Universidade do Vale do Rio dos Sinos - UNISINOS \\ Avenida Unisinos, 950, 93022-000, São Leopoldo, RS, Brazil.
}

Ely Laureano Paiva

E-mail address: ely.paiva@fgv.br Fundação Getulio Vargas - EAESP/FGV

Fundação Getulio Vargas, Av. 9 de Julho, 2029, Bela Vista, 01313-902, São Paulo, SP, Brazil.

Andrew Beheregarai Finger

E-mail address: finger.andrew@gmail.com

Universidade Federal de Alagoas - UFAL Av. Lourival de Melo Mota, Bloco 16, $1^{\circ}$ andar, 57072-970, Maceió, AL, Brazil.

Rafael Teixeira

E-mail address: rafaelte@ unisinos.br Universidade do Vale do Rio dos Sinos - UNISINOS Avenida Unisinos, 950, 93022-000, São Leopoldo, RS, Brazil.

Received 11 May 2012; received in revised form 23 November 2012 (this paper has been with the authors for two revisions); accepted 27 November 2012; published online 16 April 2013. 


\begin{abstract}
This paper investigates if regional differences are able to influence trust-based relationship with suppliers. It presents the results of a survey of 338 processing plants located in Western and Asian countries using structural equation modeling. Findings suggest that supplier involvement in quality is taken for granted, but it is not related to trust or partnership. Regional differences may also affect the development of partnership in the supply chain. The two main aspects are the levels of trust and timeliness in Asian companies. These aspects bring implications for managers dealing with international supply chains.
\end{abstract}

Key words: trust; supply chain partnership; supply chain management; survey. 


\section{Introduction}

The supply chain is a phenomenon which always occurs when companies establish relationships, independent of the level of management existent. This statement distinguishes the supply chain from supply chain management (SCM), meaning that the latter is the systemic and strategic coordination of tasks among different companies that are part of a supply chain, aiming to improve each company's performance as well as the overall supply chain (Mentzer et al., 2001). Lately, SCs are becoming global, continuously connecting companies from different institutional contexts (MacDuffie, 2011). A strategic orientation in supply chain management is a key aspect to be competitive (Yeung, 2008) and trust has been pointed out as an asset for long-term partnerships (Cannon, Doney, Mullen, \& Petersen, 2010). However, there are still some gaps in the literature on supply chain management. First, there are few studies comparing the level of trust existing in supply chain partnerships established in different countries, as noted by Dyer and Chu (2011). These authors recommend that future research should explore the conditions in which trust occurs. Second, other authors have conceptualized the influence several factors have on trust (Laeequddin, Sahay, Sahay, \& Waheed, 2012) but have not explored the potential influence of supply chain characteristics, such as supply involvement in new product development and quality of buyer's products. For example, investigating suppliers in South Korea, Oh and Rhee (2010) found that supplier production capabilities positively influence collaboration with buyers. However, as noted by Pagell, Katz, Sheu (2005), national culture has an effect on operations management, and differences among countries or global regions should be taken into account in studies. We follow this line of reasoning and investigate how trust is influenced by supply chain factors in different global regions by asking: What are the aspects that influence trust-based relationships? Are there differences between trust-based relationships with suppliers in Western and Asian countries?

The objective of this paper is twofold. First, we want to evaluate the relationship between trustbased relationships and the following supply chain factors: supplier involvement in new product development and quality, supply partnership, and supply timeliness. By accomplishing this objective, we add to literature on supply chain management by showing how supply chain factors may be related to buyer-supplier relationships that are based on trust. Second, we want to explore whether there are regional differences related to trust-based relationships. By doing so, we provide a better understanding of how trust may be contingent upon regional differences, like cultural and institutional aspects.

This paper brings empirical data to this discussion through the results of a survey. Two groups of countries are analyzed using structural equation modeling (SEM): Western countries (some European countries, the USA and Brazil) and Asian countries (Japan, South Korea and China). Results have implications for managers who deal with multicultural contexts and international supply chains. The next section discusses the theoretical framework of trust and supply chain partnerships. Then, we describe the method applied in this research. A background of the sample follows. Finally, we discuss the main findings and outline the study's final considerations.

\section{Literature Review}

This study analyzes relationships among firms, seeking the identification of the driving forces that motivate them to collaborate (Dyer \& Chu, 2000). Harland (1996) defines supply chain management as the management of inter-business chains. Similarly, Charvet, Cooper and Gardner (2008) consider that a relevant stream of the current literature on SCM focuses on causal links between supply chain members (at least, a dyadic perspective). Trust would appear as an input or output of the supply chain management. The following discussion provides support for this research. 


\section{Trust}

The study of trust began in economics and sociology, which have approached the institutional environment and inter-firm arrangements from different perspectives. Both areas of knowledge have some common interests that influence the way that supply chain management has been studied. However, sociology and economics view the issue from different perspectives. Institutional economics assumes opportunistic behavior as the norm. To the contrary, sociology pays special attention to the emergence and diffusion of trust in relationships (personal and institutional).

A number of scholars using a sociology basis have suggested that a variety of macro-level structures, including networks and governance, enhance the emergence and diffusion of trust. Trust involves at least two agents: the trustor (organization, product, institution) and the trustee (Lane \& Bachmann, 1998; Nooteboom, 2002; Zucker, 1986). We considered in this paper that trust is "the extent to which one believes that others will not act to exploit one's vulnerabilities" (Morrow, Hansen $\&$ Pearson, 2004). Thus, both agents are simultaneously trustor and trustee.

\section{Trust and supply chain relations}

Morrow, Hansen and Pearson (2004) highlight the challenge of studying inter-organizational trust as only individuals, and not organizations as a whole, are capable of trust. Batt (2000) asks, for example, who is able to develop trust, the salesperson or the sales organization? Organizations and individuals may pursue their self-interests by forming relationships with others to economize on transaction costs (Batt, 2000; Lindgreen, 2003; Morrow et al., 2004; Sako, 1992). Examples are the sharing of information on bad payers, reducing the need to inspect quality or the need to organize payment at the time of delivery. Besides reducing transaction costs, the reduction of uncertainty and information asymmetry is an important consequence of a trusting relationship (Dyer \& Chu, 2003). There has been some criticism regarding the use of transaction cost, as it focuses on dyadic relationships and cannot really identify interdependence across chains. It also fails to analyze the institutional complexity, change and power existent in business relationships (Cox, Lonsdale, Sanderson, \& Watson, 2004; Dubois, Hulthén, \& Pedersen, 2004).

Trust is a key factor for the development of partnerships among the different agents of a supply chain, distinguished between interpersonal and inter-firm trust (Johnston, Mccutcheon, Stuart, \& Kerwood, 2004). The creation of trust in inter-firm relationships can be considered related to a country's cultural context (Dyer \& Chu, 2003; Sako, 1992; Zaheer \& Zaheer, 2006). In this sense, Dyer and Chu (2000), in their meritorious study, found significant levels of supplier trust in the US, Japan and Korea. These differences are related to the institutional environment. These authors suggest that supplier trust depends on frequency and long-term interactions (which they called process based trust). However, they also admit that the automaker buyers studied incur additional costs while developing this kind of relationship.

\section{Supplier involvement}

First, it is crucial to define involvement. We consider involvement as "the act of sharing in the activities of a group" (Webster's, 2008, p. 711). Therefore, according to our definition, partnership is a more advanced state in a relationship between buyers and suppliers than involvement. Involvement is a condition for partnership but it is possible that involvement is present in some situations of relationship while trust and partnership are not.

The literature on new product development has provided evidence suggesting that supplier involvement may positively contribute to improve buyer ability to develop new products (Brown \& Eisenhardt, 1995; Montoya-Weiss \& Calantone, 1994; Ragatz, Handfield, \& Petersen, 2002; Song \& Benedetto, 2008). These contributions by suppliers to buyer ability to develop new products are somewhat related to trustworthy relationships between buyers and suppliers. Dyer's works (Dyer \& Chu, 2000, 2003) and Zaheer, McEvily and Perrone (1998) have contributed to provide an 
understanding of how trust-based relationship can reduce opportunistic behavior by suppliers and improve their contribution to new product development. High levels of trust reduce the need for buyers and suppliers to spend long periods of time and effort during meetings to negotiate and write complex contracts in order to safeguard their investments in the relationship. By reducing the time and effort required to negotiate and monitor the relationship, buyers and suppliers can focus on one activity that mostly contributes to new product development: information exchange between parties. Information exchange can help the buyer obtain information about innovation occurring on the supplier side. In this case, new components and product parts can contribute to incremental and even radical product development.

\section{Hypotheses}

\section{Supplier involvement and trust}

Supplier involvement in quality tends to influence the trust between buyers and suppliers because it demonstrates supplier commitment to the quality of its outputs. In this case, better supplier outputs mean better buyer inputs into the production system, influencing buyer performance (Chopra $\&$ Mendl, 2010). Trust may also reduce the need for buyers to monitor supplier deliveries and quality of inputs as well as reduce the need to enforce penalties in the case of lower quality inputs (Dyer \& $\mathrm{Chu}, 2003)$. In this case, supplier involvement in quality may become a first step for commitment in a relationship and contribute to an improving cycle of trust: increasing quality may lead to reduction in transaction costs, which in turn improves trust, reinforcing the relationship and rewarding supplier involvement in quality. Finally, supplier involvement in quality may be a form of aligning interests with the buyer and contribute to a trustworthy relationship (Dyer \& Nobeoka, 2000; Ireland \& Webb, 2007).

H1A. Supplier involvement in quality positively influences trust.

The literature on new product development has provided evidence suggesting that supplier involvement may positively contribute to improve buyer ability to develop new products (Brown \& Eisenhardt, 1995; Montoya-Weiss \& Calantone, 1994; Ragatz et al., 2002; Song \& Benedetto, 2008). Supplier involvement in new product development also tends to influence the development of a trustbased relationship because suppliers can provide information feedback about materials, pricing, and process capabilities for improvements in product performance, as recently demonstrated by empirical studies (Koufteros, Cheng, \& Lai, 2007; Narasimhan \& Jayaram 1998; Quesada, Rachamadugu, Gonzalez, \& Martinez, 2008).

H1B. Supplier involvement in new product development influences positively trust.

\section{Trust and supply chain partnership}

Supply chain partnership (SCP) theory says that companies involved in frequent and long-term transactions are often offered incentives to not engage in opportunistic behavior, over time encouraging them to create trust (Croom, 2001; Zsidisin \& Ellram, 2001). According to Pyke and Johnson (2003), companies use different approaches to manage their suppliers, one way is the establishment of alliances and partnerships. Similarly, increasing pressure for better performance in aspects like cost reduction and product development leads companies to focuses on supply chain partners and supply integration (Flynn, Huo, \& Zhao, 2010; Sheth \& Sharma, 2006). Trust can assume two different roles in a partnership: an input or an output. In the first role, the previous existence of trust can be transferred to a business partnership. This may happen at the initial development stage of a business relationship (Heffernan, 2004). The second role involves a more rational and calculated kind of trust between two business partners. In both cases, the aim is to move closer to a vertically integrated supply chain. 
The uncertainty surrounding a business transaction can assume different levels. On one hand, for the buyer, it can be an uncertainty of quality, a reliable supply, timeliness or quantity. On the other hand, it can be the seller searching for a buyer. For both agents, price can be uncertain (Hobbs \& Young, 2000). It is worth pointing out that uncertainty, one of the features of transaction costs, as well as partnerships are able to influence trust in a buyer-supplier relationship. In our study, we consider supply timeliness related to uncertainty. A high level of supply timeliness leads to lower uncertainty. We define timeliness as "the quality of arriving on time" (Webster's, 2008, p. 1397).

H2. Supplier partnership positively influences trust.

H3. Supply timeliness positively influences trust.

\section{Regional aspects and trust}

Regional and cultural differences can influence supply chain partnerships and the kind of role that trust assumes. Harland (1996) compared supply chains based in two European countries, the United Kingdom and Spain and found that Spanish relationships were more supportive and trust oriented, but they did not perform better than the British ones according to customer perception.

Supply chain partnerships happen in distinguished ways. Vereecke and Muylle (2006) identified two kinds of SC collaboration: information sharing (exchange of forecasting, planning and delivery information) and structural collaboration (such as Kan-ban system and co-location of plants). They empirically tested SC collaboration effects on performance improvements in engineering and assembling industries in 16 countries for the period of 2000-2002 and concluded that collaboration with both customers and suppliers results in maximum performance improvement.

Johnston, McCutcheon, Stuart and Kerwood (2004) developed a model to understand that the major determinants of buyer satisfaction are supplier performance. They also showed that increased cooperative behavior leads to higher performance and satisfaction. This also highlights the importance of building trust between buyers and suppliers. Their findings came from a broad range of buyer organizations from both public and private sectors (cross-sectional) and confirmed that cooperative behavior is associated with higher levels of trust.

Mentzer, Myers and Stank (2007) indicate that the next generation of competitive advantage may come from effective relationships with supply chain partners, as soon as firms realize that collaborative business relationships improve their ability to respond to new business environments. This happens by allowing them to focus on their core business and to reduce costs in business processes.

These collaborations and partnerships in the supply chain are defined as the means by which companies within the supply chain work together towards mutual objectives, sharing ideas, information, knowledge, risks, rewards, and solutions to common problems (Benton, 2007; Bowersox, Closs, \& Cooper, 2002; Cohen \& Roussel, 2004).

Table 1 proposes distinct forms of supply chain configuration according to the level of integration existing throughout the supply chain. 
Table 1

\section{Forms of Supply Chain Configuration}

\begin{tabular}{ll}
\hline $\begin{array}{l}\text { Supply Chain } \\
\text { Configuration }\end{array}$ & Characteristics \\
\hline Spot market & $\begin{array}{l}\text { Companies do not collaborate on the production system, which is considered } \\
\text { standardized. Risks to the buyer are low due to supplier ability to meet requirements. }\end{array}$ \\
Partnership & $\begin{array}{l}\text { Cooperation between more or less equals - firms with the same level of power, size } \\
\text { and/or technology. High and generalized competence favors networks and reciprocal } \\
\text { inter-dependence. It may also include contracts. }\end{array}$ \\
Quasi-integration & $\begin{array}{l}\text { Usually, characterized by the existence of contracts. High degree of buyer control over } \\
\text { supplier; buyer defines the product. The buyer would incur losses from supplier } \\
\text { performance failures, and there are some doubts about supplier competence. Where high } \\
\text { supplier competence is not generalized, buyers invest in specific suppliers and seek to tie } \\
\text { them to their chain. } \\
\text { The risks of poor performance by independent suppliers increase if the buyer uses quality } \\
\text { as a brand attribute. These factors favor direct control over the production process. }\end{array}$
\end{tabular}

Note. Source: Adapted from Humphrey, J., \& Schmitz, H. (2002). How does insertion in global value chains affect upgrading in industrial clusters? (p. 16). Regional Studies, 36(9), 1017-1027. doi: 10.1080/0034340022000022198

A characterization of supply chain types is suggested in this table. For Humphrey and Schmitz (2002), cooperation between companies of the same size and comparable power is called a partnership. Alternatively, when the relationship is characterized by a stronger or larger company dictating the norms and standards to a group of small and medium sized companies (also known as a hub and spoke network), it is called quasi-integration. The latter also exemplifies the power asymmetry that may exist in a buyer-supplier relationship.

For Lambert (2006) the term partnership it is still the most descriptive term for closely integrated and mutually beneficial relationships that enhance supply chain performance. But the relationships within the supply chain will occur in many different styles of relationships and change those suppliers among the different styles depending on their performance over time. The increasing internationalization of supply chains, with the presence of international players, is quickly changing transaction features. These relationships tend to be hierarchical but are changing to become more trustbased because of the increasing need to quickly respond to changing competitive criteria (Griffith \& Myers, 2005).

H4. The relationship between supply and trust is influenced by regional aspects.

\section{Method}

Data collection came from a survey methodology based on the database of the High Performance Manufacturing project (Schroeder \& Flynn, 2001). The sample has 338 plants from three different industries: electronics, machinery and automotive suppliers. Plants are located in Austria (21), China (51), Finland (30), Germany (41), Italy (27), Japan (35), Spain (28), South Korea (31), Sweden (24), United States (29) and Brazil (21). The scales used a Likert scale with seven levels from (1) Totally Disagree to (7) Totally Agree.

High Performance Manufacturing (HPM) started in 1989 in the United States. In the second round only the United States and Japan participated in the project. In the third round the international research group included new constructs and 11 countries collected the data. The third round finished gathering data in 2010. Only during this round did the Brazilian group replicate the questionnaire, 
because by this period the questions had already been defined. At the beginning of each round, the group revised the scales and translated the questionnaire before application in the different countries. The use of back translation was mandatory in all countries where English is not the native language. A longitudinal perspective was not considered, since the data gathered in the three rounds did not present the same companies and there were changes in the scales. The data collected in each country are sent to one researcher that is responsible for the complete database. Fourteen people from the companies answered the questions concerning internal areas, including plant manager, quality manager and supply manager, among others. As the project seeks to understand and compare the practice of highperforming manufacturers located in different countries, the sample is based on plants that are considered best practices in their countries.

We used confirmatory factor analysis (CFA) to verify validity and reliability. The CFA model included the constructs related to Supplier Involvement in New Product Development, Supplier Involvement in Quality, Supplier Partnership, Trust and Supply Timeliness. All the constructs with the exception of Supply Timeliness were previously defined in the High Performance Manufacturing project questionnaire. Appendix presents the items and theoretical references from Table A1.

Table A2 presents the indices related to the goodness-of-fit, which are at satisfactory levels. Also all the loadings are above .60, confirming convergent validity (Appendix).

Table 2

\section{General Statistics for Goodness-of-fit}

\begin{tabular}{lc}
\hline Stand Alone Indices & \\
\hline Chi-Square & 245.18 \\
Degrees of Freedom (df) & 94 \\
Probability Level & .00 \\
Goodness of Fit (GFI) & .915 \\
Adjusted Goodness of Fit (AGFI) & .877 \\
Standardized RMR & .043 \\
RMSEA & .069 \\
\hline Incremental Indices & \\
\hline Normed Fit Index (NFI) & .888 \\
Incremental Fit Index (IFI) & .928 \\
Comparative Fit Index (CFI) & .927 \\
\hline
\end{tabular}

In order to analyze discriminant validity we used the X2 difference (Koufteros, 1999). The constructs presented statistically significant differences, when the correlation between them was fixed at 1 (see Table 3). 
Table 3

\section{Discriminant Validity Analysis}

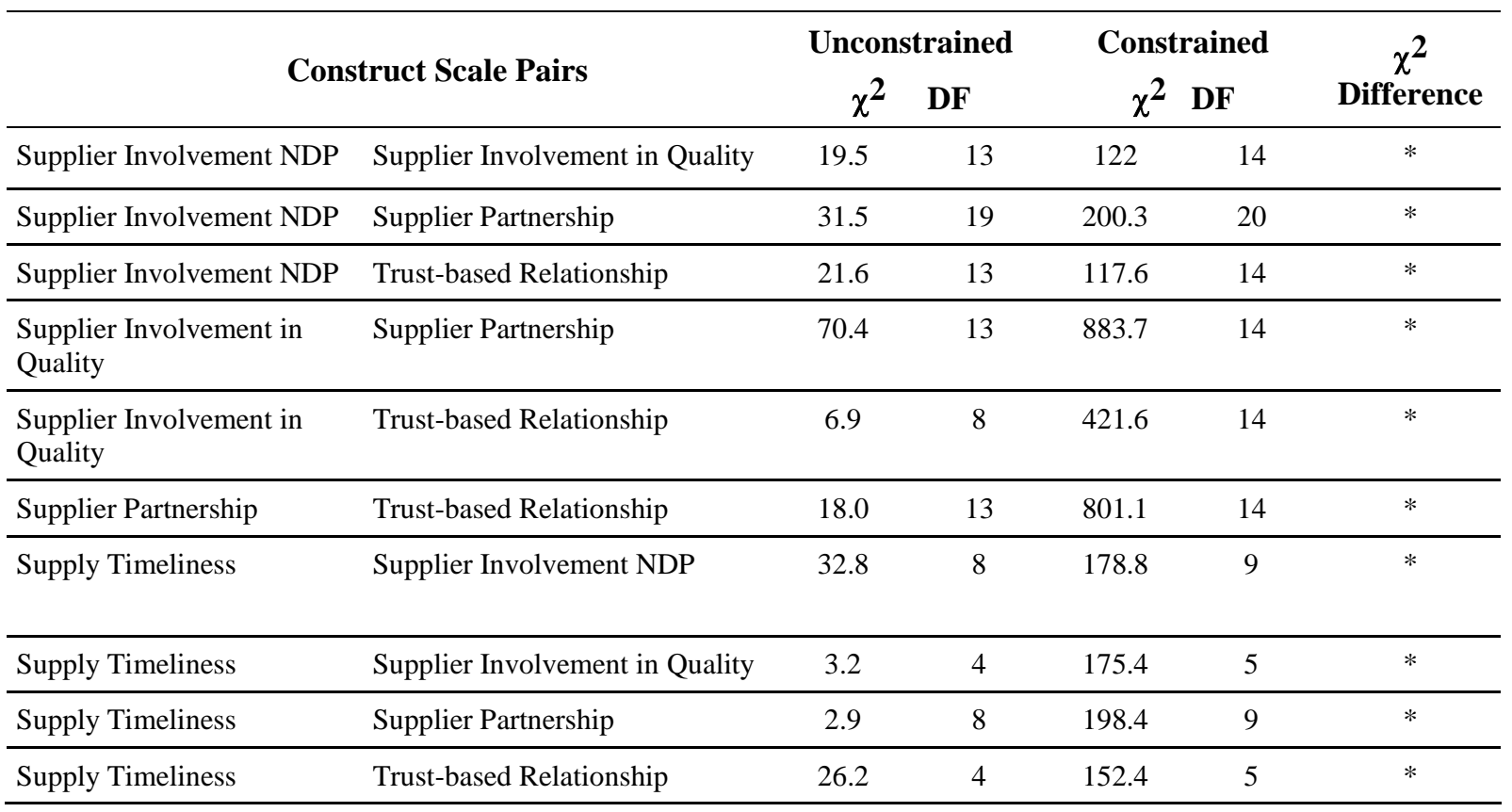

We tested if aspects related to Supply Chain Management aspects may affect trust. We used a stepwise regression analysis technique. We also tested if these aspects are related to regional issues related to each of the two regions.

Two groups of countries were analyzed using structural equation modeling (SEM): Western (Europe, USA and Brazil) and Asian countries (Japan, South Korea and China). 221 plants were located in Western countries and 117 in Asia.

The stepwise regression analysis was employed to test two models. The first model has Trust as the dependable variable and Supplier Involvement in New Product Development, Supplier Involvement in Quality, Supplier Partnership, and Supply Timeliness as independent variables. The second model is designed to test hypothesis 4 . To do so, we added a dummy variable for Western (equal to 0 ) and Asian (equal to 1) countries to the independent variables already in the first model.

\section{Results}

The results are shown in Table 4. R2 change from first to second model is significant (R2 change $=0.015$; F-test $=7.233$; $\mathrm{Sig}=0.008$ ), indicating that the inclusion of the dummy variable contribute to better explained the variance in the dependent variable Trust. Also results show a good $\mathrm{R}^{2}$ (.358) for a social science study, indicating that the model has a satisfactory explanation power for the Trust variance. 
Table 4

\section{Stepwise Regression Analysis Results}

\begin{tabular}{lccccc}
\hline & \multicolumn{2}{c}{$\begin{array}{c}\text { Unstandardized } \\
\text { Coefficients }\end{array}$} & $\begin{array}{c}\text { Standardized } \\
\text { Coefficients }\end{array}$ & & \\
\cline { 2 - 4 } Model & $\mathbf{B}$ & Std. Error & Beta & t & Sig. \\
\hline (Constant) & 1.249 & .330 & & 3.782 & .000 \\
Supplier Involv. NDP & .025 & .026 & .046 & .960 & .338 \\
Supplier Involv. Quality & .087 & .074 & .087 & 1.182 & .238 \\
Supplier Partnership & .282 & .086 & .246 & 3.267 & .001 \\
Supply Timeliness & .367 & .045 & .394 & 8.092 & .000 \\
\hline
\end{tabular}

Dependent variable Trust-based relationship

$\mathrm{R}^{2}=.335$

\begin{tabular}{lccccc}
\hline & \multicolumn{2}{c}{$\begin{array}{c}\text { Unstandardized } \\
\text { Coefficients }\end{array}$} & $\begin{array}{c}\text { Standardized } \\
\text { Coefficients }\end{array}$ & & \\
\cline { 2 - 4 } Model & B & Std. Error & Beta & t & Sig. \\
\hline (Constant) & 1.255 & .589 & & 2.128 & .034 \\
Supplier Involv. NDP & .023 & .025 & .043 & .900 & .369 \\
Supplier Involv. Quality & .100 & .073 & .100 & 1.362 & .174 \\
Supplier Partnership & .289 & .086 & .252 & 3.361 & .001 \\
Supply Timeliness & .336 & .046 & .360 & 7.223 & .000 \\
Region (dummy) & .159 & .059 & .127 & 2.681 & .008 \\
Dependent variable Trust-based relationship & & & & \\
$\mathrm{R}^{2}=.358$ & & & & & \\
\hline
\end{tabular}

There is not enough evidence to confirm our first hypothesis. Supplier Involvement in NPD as well in Quality did not present a statistically significant result for Trust-based relationships. This means that supplier involvement with buyer processes is not related to a trust-based relationship between buyer and supplier. This result may be explained by power asymmetry in the supply chain. We may conjecture that a supplier may be pressured by a buyer with high bargaining power to participate in processes related to NPD and quality improvement. This is also supported by Humphrey and Schmitz (2002), who asserted similar characteristics for when a relationship involves companies of different sizes or the supplier involvement is stated in a contract. Even this makes it is possible to achieve satisfactory results for both supplier and buyer. Nevertheless, this type of activity is not enough for the existence of a trust-based relationship. Eventually, this involvement and frequency of transactions may evolve to a more trust-based relationship (as a cycle), but our findings do not measure this dynamicity. In this case, other aspects related to, for example, low levels of uncertainty are more important than only involvement in this type of activities. Another explanation may be the fact that these processes are formally established in contracts between a buyer and its suppliers. For example, a buyer may have a formal program for supplier participation in new product development or quality. Such a formal program may be based on a contract that protects both parties during the involvement of suppliers in buyer's processes. In this case, contracts may serve as a basis for the relationship rather than trust.

On the other hand, Hypothesis 2 was confirmed. Supplier Partnership is positively related to trust, as expected. This result is supported by the literature (Croom, 2001; Zsidisin \& Ellram, 2001). 
Aspects such as sharing problems with our suppliers, searching for more effective solutions with suppliers, belief that cooperating with our suppliers is beneficial and openness of communications with suppliers are clearly related to trust-based relationships. Thus, trust is an output of a supply chain partnership, being characterized by rationality when aiming for a win-win situation (Morrow et al., 2004).

Hypothesis 3 was also confirmed. The results show that working with short lead times makes it easier for buyers to interact with suppliers. Thus, suppliers are able to quickly respond to possible changes in demand, and certainly uncertainty is lower than when the opposite occurs. Supply Timeliness is positively related to Trust. This is also aligned to the transaction cost theory that says that uncertainty of timeliness negatively affects trust and consequently long-term relationships. At the same time, short lead-time is one of the key aspects in the lean production system that is culturally linked to Asian countries.

Finally, we may state that regional context may influence the kind of relationship among suppliers and buyers according to the results found in the stepwise regression analysis presented. As shown in Table 4, for Asian companies the influence of Supplier Partnership and Supply Timeliness presents higher levels of influence on trust when compared to the Western companies in the sample because the inclusion of the dummy variable related to region location presented a significant statistical result in the second regression analysis. This result is partially supported by evidence found in previous studies about differences in Eastern and Western countries. Our results extend these previous findings by providing evidence that suggests that trust-based relationships in supply chains are related to the regional context where the buyer and supplier are located. These results are aligned to the institutional trust characteristic of Asian countries (Sako, 1992). Our sample also expands the discussion on cross-cultural studies and trust-based relationships initiated by Dyer and Chu (2000, 2003, 2011). In this sense, Western and Asian companies develop supply chain partnerships in different ways in order to manage their suppliers.

\section{Conclusions}

The first finding related to this study is related to the difference between involvement and partnership. As the first hypothesis was not confirmed, we may conjecture that companies may participate in improvement or new product development processes with their customers but this is not a pre-existing condition for the existence of trust or partnership between a supplier and buyer. A possible explanation for this is a buyer with high levels of power may force their suppliers to participate in such processes; but a partnership or trust-based relationship requires other aspects, such as a long-term view or low levels of uncertainty. As speculated before, buyers can also use contract mechanisms to have suppliers involved in new product development and quality programs. In past studies involving Asian companies, like Dyer and Chu (2003) or Sako (1992), trust is present because in many cases the buyers are in a highly integrated system like a Keiretsu. New studies may explore how companies in market-based relationships may create ways to improve trust. $\mathrm{Li}$, Zhao and $\mathrm{Qu}$ (2012) explored the commitment as one key aspect for partnership. Chen, Huang, and Sternquist (2011) also identified that Guanxi practices are positively related to commitment. Thus, scales that include long-term views, formal contracts and commitment may show how they are important when companies develop partnership initiatives.

The information flow alone cannot be considered a condition for trust as it can be just a transfer of technical standards. Besides, the size of the companies involved in the supply chain relationship, the country of origin (developed or developing country), the asset specificity involved in the business transaction and the use of contracts are factors that can influence the supplier involvement. The second and third hypotheses were confirmed as expected. Literature on supply chain has shown that partnership and low uncertainty are related to trust. Both aspects are able to diminish opportunistic behavior within the transaction cost approach. This is considered a rational understanding of trust, 
where the two agents (buyer and supplier) perceive the relationship advantageous for both sides. Our study corroborates this perspective by showing evidence suggesting that partnership and timeliness are related to trust-based relationship.

Regional aspects are present in the aspects analyzed. Thus, the fourth hypothesis was confirmed. We may state that these two aspects (partnership and timeliness) are more present in companies located in Asian countries than in companies located in Western countries. Probably the lean philosophy is a powerful explanation in the case of Japanese companies. Also, supply chain configuration, such as the Japanese Keiretsu or the Korean Chaebol, may create trust between partners (Narasimhan \& Kim, 2002). For the Chinese companies, Guanxi regarding favors, obligations and preferential treatment is a possible cause of trust-based relationships (Lee \& Dawes, 2005). Western companies may make use of contracts and other safeguards to develop supply chain relationships but they do not evolve into trust-based relationships.

This study contributes to strategic purchasing managers from Western and Asian countries. Although literature on SCM points out partnership and quasi-integration strategies as the most successful way to achieve better performance, our study suggests that there are distinct aspects to consider depending upon where the processing plant is located. These certainly influence supply chain management.

As limitations of this study we may cite the sample's firm characteristic, which is composed of only three industries and impedes generalization for firms in other industries. As another limitation of this study we may cite that the two groups of countries also have distinctive cultural and institutional aspects. The increasing internationalization of supply chains may also affect current business practices. Another limitation in our sample is the focus on manufacturing firms, leaving service firms out the study. A further limitation is the level of analysis that focuses on trust-based relationship between organizations but does not take into account trust-based relationship between managers and employees of these organizations, since it is these managers and employees who really act in terms of trusting one another.

As suggestions for future studies, we encourage scholars to investigated trust-based relationships between buyers and suppliers in other industries, so we can have enough evidence to make more robust conclusions about this issue. We also encourage scholars to develop studies about trust in service supply chains, which have special characteristics that may lead to new insights about this topic. For example, how can trust help suppliers to be engaged in buyers' new service development activities? We also suggest scholars to conduct studies with a multilevel analysis perspective, considering managers and employees nested within organizations. This approach may render additional insights about the effects of organizations on the trust developed between buyers' and suppliers' managers. For example, are there some organizations (e.g. buyers) with characteristics that lead managers and employees to trust more or less in their counterparts from other organizations (e.g. suppliers)? Future studies can also measure the frequency of business transaction and asset specificity in terms of how they influence the different levels of trust. In addition, we suggest measuring the levels of trust based on supply chain performance. Longitudinal studies can also contribute to verify if there is standardization occurring in business transactions according to industry.

\section{References}

Batt, P. J. (2000). Strategic lessons to emerge from an analysis of selected flower export nations. Journal of International Food and Agribusiness Marketing, 11(3), 41-73. doi: 10.1300/J047v11n03_03

Benton, W. C. (2007). Purchasing and supply chain management. New York: Mcgraw-Hill. 
Bowersox, D. J., Closs, D. J., \& Cooper, M. B. (2002). Supply chain logistics management. New York: Mcgraw-Hill.

Brown, S. L., \& Eisenhardt, K. M. (1995). Product development, past research, present findings, and future directions. Academy of Management Review, 20(2), 343-378. doi: 10.2307/258850

Cannon, J. P., Doney, P. M., Mullen, M. R., \& Petersen, K. J. (2010). Building long-term orientation in buyer-supplier relationships: the moderating role of culture. Journal of Operations Management, 28(6), 506-521. doi: 10.1016/j.jom.2010.02.002

Charvet, F. F., Cooper, M. C., \& Gardner, J. T. (2008). The intellectual structure of supply chain management: a bibliometric approach. Journal of Business Logistics, 29(1), 47-73. doi: 10.1002/j.2158-1592.2008.tb00068.x

Chen, Z., Huang, Y., \& Sternquist, B. (2011). Guanxi practice and Chinese buyer-supplier relationships: the buyer's perspective. Industrial Marketing Management, 40(4), 569-580. doi: 10.1016/j.indmarman.2010.12.013

Chopra, S., \& Meindl, P. (2010). Supply chain management, strategy, planning, \& operation. New York: Prentice Hall.

Cohen, S., \& Roussel, J. (2004). Strategic supply chain management. New York: McGraw-Hill.

Cox, A., Lonsdale, C., Sanderson, J., \& Watson, G. (2004). Managing appropriately in power regimes, relationship and performance management in 12 supply chain cases. Supply Chain Management: An International Journal, 9(5), 357-371. doi: 10.1108/13598540410560748

Croom, S. (2001). Restructuring supply chains through information channel innovation. International Journal of Operations \& Production Management, 21(4), 504-515. doi: $10.1108 / 01443570110381408$

Dubois, A., Hulthén, K., \& Pedersen A. (2004). Supply chains and interdependence, a theoretical analysis. Journal of Purchasing \& Supply Management, 10(1), 3-9. doi: 10.1016/j.pursup.2003.11.003

Dyer, J. H., \& Chu, W. (2000). The determinants of trust in supplier-automaker relationships in the U.S., Japan, \& Korea. Journal of International Business Studies, 31(2), 259-285. doi: 10.1057/palgrave.jibs.8490905

Dyer, J. H., \& Chu, W. (2003). The role of trustworthiness in reducing transaction costs \& improving performance, empirical evidence from United States, Japan, \& Korea. Organization Science, 14(1), 57-68. doi: 10.1287/orsc.14.1.57.12806

Dyer, J. H., \& Chu, W. (2011). The determinants of trust in supplier-automaker relations in the US, Japan \& Korea: a retrospective. Journal of International Business Studies, 42(1), 28-34. doi: $10.1057 /$ jibs.2010.48

Dyer, J. H., \& Nobeoka, K. (2000). Creating and managing a high- performance knowledge-sharing network: the Toyota case. Strategic Management Journal, 21(3), 345-367. doi: 10.1002/(SICI)1097-0266(200003)21:3<345::AID-SMJ96>3.0.CO;2-N

Flynn, B. B., Huo, B., \& Zhao, X. (2010). The impact of supply chain integration on performance: a contingency and configuration approach. Journal of Operations Management, 28(1), 58-71. doi: 10.1016/j.jom.2009.06.001

Griffith, D. A., \& Myers, M. B. (2005). The performance implications of strategic fit of relational norm governance strategies in global supply chain relationships. Journal of International Business Studies, 36(3), 254-269. doi:10.1057/palgrave.jibs.8400131 
Harland, C. M. (1996). Supply chain management, relationships, chains \& networks. British Journal of Management, 7(s1), 163-180. doi: 10.1111/j.1467-8551.1996.tb00148.x

Heffernan, T. W. (2004). Trust formation in cross-cultural business to business relationships. The International Journal of Qualitative Marketing Research, 7(2), 114-125. doi: $10.1108 / 13522750410530020$

Hobbs, J. E., \& Young, L. M. (2000). Closer vertical coordination in agrifood supply chains, a conceptual framework and some preliminary evidence. Supply Chain Management, 5(3), 131142. doi: $10.1108 / 13598540010338884$

Humphrey, J., \& Schmitz, H. (2002). How does insertion in global value chains affect upgrading in industrial clusters? Regional Studies, 36(9), 1017-1027. doi: 10.1080/0034340022000022198

Ireland, D. R., \& Webb, J. W. (2007). A multi-theoretic perspective on trust and power in strategic supply chains. Journal of Operations Management, 25(2), 482-497. doi: 10.1016/j.jom.2006.05.004

Johnston, D. A., Mccutcheon, D. D., Stuart, I. F., \& Kerwood, H. (2004). Effects of supplier trust on performance of cooperative supplier relationships. Journal of Operation Management, 22(1), 23-38. doi: 10.1016/j.jom.2003.12.001

Koufteros, X. A. (1999). Testing a model of pull production: a paradigm for manufacturing research using structural equation modeling. Journal of Operations Management, 17(4), 467-488. doi: 10.1016/S0272-6963(99)00002-9

Koufteros, X. A., Cheng, T. C. E., \& Lai, K-H. (2007). "Black-box" and "gray-box" supplier integration in product development: antecedents, consequences $\&$ the moderating role of firm size. Journal of Operations Management, 25(4), 847-870. doi: 10.1016/j.jom.2006.10.009

Laeequddin, M., Sahay, B. S., Sahay, V., \& Waheed, K. A. (2012). Trust building in supply chain partners relationship: an integrated conceptual mode. Journal of Management Development, 31(6), 550-564. doi: 10.1108/02621711211230858

Lambert, D. M. (Ed.). (2006). Supply chain management: processes, partnerships, performance (2nd ed.). Sarasota: SCM Institute.

Lane, C., \& Bachmann, R. (1998). Trust within and between organizations, conceptual issues \& empirical applications. Oxford: Oxford University Press.

Lee, D. Y., \& Dawes, P. L. (2005). Guanxi, trust and long-term orientation in Chinese business markets. Journal of International Marketing, 13(2), 28-56. doi: 10.1509/jimk.13.2.28.64860

Li, W., Zhao, P., \& Qu, H. (2012). The empirical research of the effect about communication, trust and commitment on supply chain cooperation. Advanced Materials Research, 468-471. 29632969. doi: 10.4028/www.scientific.net/AMR.468-471.2963

Lindgreen, A. (2003). Trust as a valuable strategic variable in the food industry, different types of trust and their implementation. British Food Journal, 105(6), 310-327. doi: $10.1108 / 00070700310481694$

MacDuffie, J. P. (2011). Inter-organizational trust and the dynamics of distrust. Journal of International Business Studies, 42(1), 35-47. doi: 10.1057/jibs.2010.54

Mentzer, J. T., DeWitt, W., Keebler, J. S., Min, S., Nix, N. W., Smith, C. D., \& Zacharia, Z. G. (2001). Defining supply chain management. Journal of Business Logistics, 22(2), 1-25. doi: 10.1002/j.2158-1592.2001.tb00001.x 
Mentzer, J. T., Myers, M. B., \& Stank, T. P. (2007). Handbook of global supply chain management. Thousand Oaks: Sage Publications.

Montoya-Weiss, M. M., \& Calantone, R. (1994). Determinants of new product performance, a review and meta-analysis. Journal of Production Innovation Management, 11(5), 397-417. doi: 10.1016/0737-6782(94)90029-9

Morrow, J. L., Jr., Hansen, M. H., \& Pearson, A. L. (2004). The cognitive and affective antecedents of general trust within cooperative organizations. Journal of Managerial Issues, 16(1), 48-64.

Narasimhan, R., \& Jayaram, J. (1998). Causal linkages in supply chain management, an exploratory study of North American manufacturing firms. Decision Sciences, 29(3), 579-605. doi: 10.1111/j.1540-5915.1998.tb01355.x

Narasimhan, R., \& Kim S. W. (2002). Effect of supply chain integration on the relationship between diversification and performance: evidence from Japanese and Korean firms. Journal of Operations Management, 20(3), 303-323. doi: 10.1016/S0272-6963(02)00008-6

Nooteboom, B. (2002). Trust forms, foundations, functions, failures and figures. Cheltenham: Edward Elgar.

Oh, J., \& Rhee, S. (2010). Influences of supplier capabilities and collaboration in new car development on competitive advantage of carmakers. Management Decision, 48(5), 756-774. doi: 10.1108/00251741011043911

Pagell, M., Katz, J. P., \& Sheu, C. (2005). The importance of national culture in operations management research. International Journal of Operations and Production Management, 25(4), 371-394. doi: 10.1108/01443570510585552

Pyke, D. F., \& Johnson, M. E. (2003). The practice of supply chain management. Philip Drive Norwell: Kluwer Academic Publishers.

Quesada, G., Rachamadugu, R., Gonzalez, M., \& Martinez, J. L. (2008). Linking order winning and external supply chain integration strategies. Supply Chain Management, an International Journal, 13(4), 296-303. doi: 10.1108/13598540810882189

Ragatz, G. L., Handfield, R. B., \& Petersen, K. J. (2002). Benefits associated with supplier integration into new product development under conditions of technology uncertainty. Journal of Business Research, 55(5), 389-400. doi: 10.1016/S0148-2963(00)00158-2

Sako, M. (1992). Prices, qualityand trust. Cambridge: Cambridge University Press.

Schroeder, R. G., \& Flynn, B. B. (Orgs.). (2001). High performance manufacturing: global perspectives. New York: John Wiley \& Sons.

Sheth, J. N., \& Sharma, A. (2006). The surpluses and shortages in business-to-business marketing theory and research. Journal of Business \& Industrial Marketing, 21(7), 422-427. doi: $10.1108 / 08858620610708902$

Song, M., \& Benedetto, C. A. D. (2008). Supplier's involvement and success of radical new product development in new ventures. Journal of Operations Management, 26(1), 1-22.

Vereecke, A., \& Muylle, S. (2006). Performance improvement through supply chain collaboration in Europe. International Journal of Operations \& Production Management, 26(11), 1176-1198. doi: $10.1108 / 01443570610705818$

Webster's New College Dictionary. (2008). Boston: Houghton Mifflin Publishers Harcourt Publishing. 
Yeung, A. C. L. (2008). Strategic supply management, quality initiatives, and organizational performance. Journal of Operations Management, 26(4), 490-502. doi: 10.1016/j.jom.2007.06.004

Zaheer, A., McEvily, B., \& Perrone, V. (1998). Does trust matter? Exploring the effects of interorganizational \& interpersonal trust on performance. Organization Science, 9(2), 141-159. doi: $10.1287 /$ orsc.9.2.141

Zaheer, S., \& Zaheer, A. (2006). Trust across borders. Journal of International Business Studies, 37(1), 21-29. doi: 10.1057/palgrave.jibs. 8400180

Zsidisin, G. A., \& Ellram, L. M. (2001). Activities related to purchasing and supply management involvement in supplier alliances. International Journal of Physical Distribution \& Logistics Management, 31(9), 629-646. doi: 10.1108/09600030110408143

Zucker, L. G. (1986). Production of trust, institutional sources of economic structure, 1840-1920. Research in Organizational Behavior, 8(1), 53-111. 


\section{APPENDIX}

Table A1

Items and Theoretical References

\begin{tabular}{|c|c|c|}
\hline Items & Scale & References \\
\hline nssin01 & Suppliers were involved early in the design efforts in this project. & Koufteros et al. (2007) \\
\hline nssin 03 & $\begin{array}{l}\text { Suppliers were frequently consulted about the design of this } \\
\text { product. }\end{array}$ & Koufteros et al. (2007) \\
\hline \multirow[t]{2}{*}{ nssin 02} & \multirow[t]{2}{*}{ We partnered with suppliers for the design of this product. } & Koufteros et al. (2007) \\
\hline & & Sheth and Sharma (2006) \\
\hline \multirow[t]{2}{*}{$\mathrm{ns} \sin 05$} & \multirow{2}{*}{ Suppliers were an integral part of the design effort. } & Koufteros et al. (2007) \\
\hline & & Sheth and Sharma (2006) \\
\hline \multirow[t]{2}{*}{ qsspn02 } & \multirow{2}{*}{$\begin{array}{l}\text { Our suppliers are actively involved in our new product development } \\
\text { processes. }\end{array}$} & Dyer and Chu (2003) \\
\hline & & Quesada et al. (2008) \\
\hline \multirow[t]{2}{*}{ qsspn05 } & \multirow{2}{*}{$\begin{array}{l}\text { We maintain close communication with suppliers about quality } \\
\text { considerations and design changes. }\end{array}$} & Dyer and Chu (2003) \\
\hline & & Quesada et al. (2008) \\
\hline \multirow[t]{2}{*}{ qsspn06 } & \multirow[t]{2}{*}{ We actively engage suppliers in our efforts to improve quality. } & Dyer and Nobeoka (2000) \\
\hline & & Dyer and Chu (2003) \\
\hline \multirow[t]{2}{*}{ qssun01 } & \multirow[t]{2}{*}{ We maintain cooperative relationships with our suppliers. } & Zsidisin and Ellram (2001) \\
\hline & & Pyke and Johnson (2003) \\
\hline \multirow[t]{2}{*}{ qssun03 } & \multirow[t]{2}{*}{ We help our suppliers to improve their quality. } & Dyer and Nobeoka (2000) \\
\hline & & Dyer and Chu (2003) \\
\hline \multirow[t]{2}{*}{ qssun06 } & \multirow{2}{*}{$\begin{array}{l}\text { We maintain communication with our suppliers about quality } \\
\text { considerations and design changes. }\end{array}$} & Dyer and Nobeoka (2000) \\
\hline & & Dyer and Chu (2003) \\
\hline \multirow[t]{2}{*}{ qssun07 } & \multirow{2}{*}{$\begin{array}{l}\text { Our key suppliers provide input into our product development } \\
\text { projects. }\end{array}$} & Koufteros et al. (2007) \\
\hline & & Sheth and Sharma (2006) \\
\hline \multirow[t]{2}{*}{ pstrn01 } & \multirow[t]{2}{*}{ We are comfortable sharing problems with our suppliers. } & Croom (2001) \\
\hline & & Zsidisin and Ellram (2001) \\
\hline \multirow[t]{2}{*}{ pstrn02 } & \multirow{2}{*}{$\begin{array}{l}\text { In dealing with our suppliers, we are willing to change assumptions, } \\
\text { in order to find more effective solutions }\end{array}$} & Croom (2001) \\
\hline & & Zsidisin and Ellram (2001) \\
\hline \multirow[t]{2}{*}{ pstrn04 } & \multirow{2}{*}{$\begin{array}{l}\text { We emphasize openness of communications in collaborating with } \\
\text { our suppliers. }\end{array}$} & Croom (2001) \\
\hline & & Zsidisin and Ellram (2001) \\
\hline psltn04 & $\begin{array}{l}\text { Our company strives to shorten supplier lead time, in order to avoid } \\
\text { inventory and stockouts. }\end{array}$ & Quesada et al. (2008) \\
\hline psltn01 & We seek short lead times in the design of our supply chains. & Quesada et al. (2008) \\
\hline
\end{tabular}


Table A2

\section{Standardized Regression Weights}

\begin{tabular}{ccc}
\hline Items & Scale & Estimate \\
\hline nssin01 & Supplier Involv. NDP & .812 \\
nssin03 & Supplier Involv. NDP & .643 \\
nssin02 & Supplier Involv. NDP & .774 \\
nssin05 & Supplier Involv. NDP & .643 \\
qsspn02 & Supplier Involv. Quality & .646 \\
qsspn05 & Supplier Involv. Quality & .637 \\
qsspn06 & Supplier Involv. Quality & .809 \\
qssun01 & Supplier Partnership & .723 \\
qssun03 & Supplier Partnership & .746 \\
qssun06 & Supplier Partnership & .769 \\
qssun07 & Supplier Partnership & .690 \\
pstrn01 & Trust-based Relationship & .754 \\
pstrn02 & Trust-based Relationship & .550 \\
pstrn04 & Trust-based Relationship & .705 \\
psltn04 & Supplier Timeliness & .652 \\
psltn01 & Supplier Timeliness & .740 \\
\hline
\end{tabular}

